\title{
Visitor perceptions about cattle grazing on National Forest land
}

\author{
JOHN E. MITCHELL, GEORGE N. WALLACE AND MARCELLA D. WELLS
}

\begin{abstract}
Authors are range scientist, Rocky Mountain Forest and Range Experiment Station, Fort Collins, Colorado 80524; and associate professor and assistant professor, Department of Natural Resource Recreation and Tourism, Colorado State University, Fort Collins, Colorado S0523.
\end{abstract}

\begin{abstract}
Visitors to the Big Cimarron Watershed in the Uncompahgre National Forest, Colorado, had varying attitudes about cattle grazing. Without cuing, $9 \%$ of all visitors listed livestock as a source of interference. Local and rural Colorado residents tended to be more agreeable to livestock presence than other visitors in 1992; however, significant differences could not be detected the following year. No relationship existed between the prevalence of a perceived grazingrecreation conflict and visitors' home community size, nor the size of the community where they grew up. Visitors in dispersed campsites tended to be more critical of grazing than those in developed campgrounds. When given a choice, the number of visitors indicating that range livestock added to their stay $(34 \%)$ was no different than the number stating a negative relationship $(33 \%)$. Understanding visitor characteristics during range allotment planning may help lessen conflicts between livestock grazing and recreational usage by aiding in plan development and the design of effective interpretive programs.
\end{abstract}

Key Words: forest recreation, forest visitor, livestock grazing, conflict

Over the last 20 years, grazing on Federally managed lands has become increasingly contentious as a policy issue in the United States, partly because of rapidly expanding demands for outdoor recreation (Hartmann et al. 1988). The disagreements over policy have recently been exacerbated in parts of the Rocky Mountains, including western Colorado, where immigration from other states and enlarging populations are inducing fundamental cultural changes (Larmer and Ring 1994).

Livestock grazing is deeply rooted in western culture and sanctioned by legislation, having been first authorized on National Forest System lands by the Organic Administration

Indirect research support was provided by the Ouray District, Uncompahgre National Forest. The authors wish to thank Jim Free and his staff for assistance in obtarning field data.

Manuscript accepted 19 March 1995.
Act of 1897 and confirmed by numerous later appropriations acts (USDA Forest Service 1989). The Public Rangelands Improvement Act of 1978 (PRIA) reinforced a national policy that public rangelands were to be "managed . . . so that they become as productive as feasible for all rangeland values."

In the 16 years since the passage of PRIA, a perceptible shift of desired rangeland values has taken place. This shift has been fueled, in part, by increasing environmental activism among segments of the U.S. population (Dunlap 1991). As a result, valuations of recreation and other amenity resources have been raised in relation to commodity resources (Kaiser et al. 1988), leading to conflicts among various interest groups over Federal land management planning objectives (Burde and Lenzini 1980).

A recent survey by Brunson and Steel (1994) has shown a propensity by U.S. residents to believe that more protection should be given to fish and wildlife, and to place little confidence in livestock, mining, and oil/gas commodity interest groups. Range conservationists and other natural resource professionals are, themselves, suggesting new and divergent interpretations of multiple-use management on public lands (Brown and Harris 1992, Kessler et al. 1992).

In one of the few studies evaluating conflict between forest or rangeland user groups, Watson and Niccolucci (1992) examined the attitudes of people visiting the John Muir Wilderness in the California Sierra's to hiker-horse interactions. They found that neither the visitors' present nor childhood community sizes were related to feelings of dislike or satisfaction when encountering pack stock on a specific trip.

Our study objective was to test for relationships between visitor demographics and perceptions of livestock grazing on a forest managed for both grazing and recreation; specifically, our goal was to explain how attributes of visitors to National Forest lands might be affecting their attitudes about cattle grazing on an area known for high recreational value.

\section{Study Area}

The Cimarron River is a tributary of the Gunnison River, situated at $38^{\circ} 15^{\prime} \mathrm{N}, 107^{\circ} 30^{\prime} \mathrm{W}$, in southwestern Colorado. 


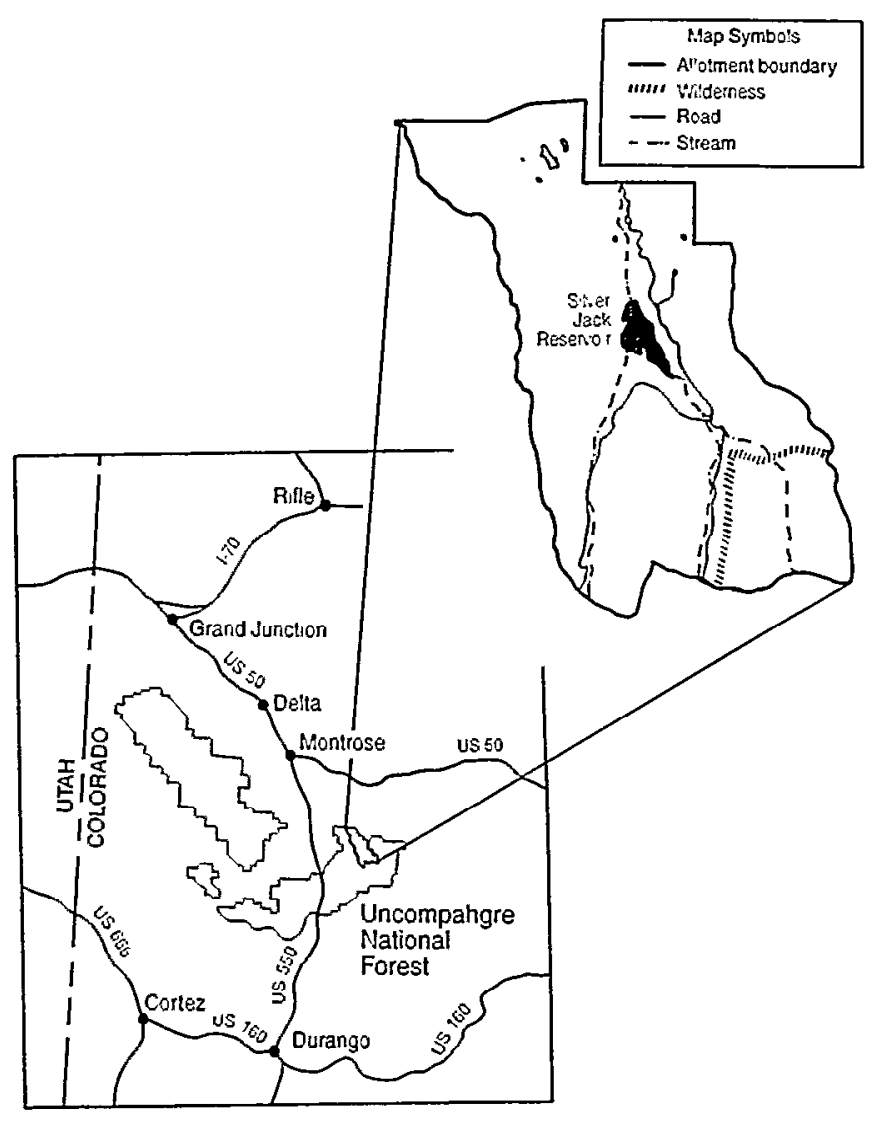

Fig. 1. Big Cimarron watershed, Ouray Ranger District, Uncompahgre National Forest, Colo.

The river's headwaters are along the Continental Divide in the Uncompahgre Wilderness Area. Two of the 3 forks of the Cimarron leave the wilderness within a few kilometers and enter managed forests and rangelands of the Ouray Ranger District, Uncompahgre National Forest (Fig. 1).

The part of the watershed under multiple-use management contains a popular reservoir with fishing facilities and 3 developed campgrounds. The campgrounds have been fenced to exclude livestock. Four unpaved roads, providing access to dispersed camping areas, numerous hiking trails, and fishing streams traverse the area. Most of the dispersed camp sites are situated along riparian areas in the forks of the Big Cimarron. Three of the roads end at trailheads leading into the wilderness area.

The Big Cimarron cattle and horse $(\mathrm{C} \& \mathrm{H})$ allotment occupies approximately 23,500 ha $(58,000$ ac.) within the Cimarron River watershed (Fig. 1). Most of the allotment is on managed forest and rangeland; however, about $10 \%$ extends into the Uncompahgre Wilderness Area. The allotment is divided into 8 pastures which are grazed by cows and their calves on a modified rotation grazing schedule that alternates every other year (Heitschmidt and Stuth 1991). The grazing season extends from mid-July to mid-October each year. Except for a few problem areas, the allotment is in satisfactory range condition (Unpublished report, Section 8 Review Team, USDA Forest Service, Denver, Colo.).
Sheep also graze the Uncompahgre Wilderness Area at elevations above the Big Cimarron $\mathrm{C} \& \mathrm{H}$ allotment. Forest visitors normally only encounter sheep if they are in the wilderness. Such encounters were too infrequent for analysis; thus, this study dealt principally with range cattle. The study area can be characterized by a historical use for cattle and sheep grazing and an increasing popularity for recreation by forest visitors, primarily to enjoy the scenic beauty and to fish (Wells 1995).

\section{Methods}

Data were collected using a questionnaire. The questionnaire was administered to a cross section of groups visiting the Big Cimarron C\&H Allotment between June and October 1992 , and again during the same period in 1993. In most instances visitor groups were personally approached and asked to participate in the survey; however, visitors stopping along travel corridors or at trailheads were given the option of mailing back the questionnaire. The survey was introduced as only a visitor perception study so that respondents would not be cued that livestock grazing was the prominent issue. In each case instructions for completing the questionnaire were provided, along with a pencil, in a ziplock plastic bag. Mailback participants also received a stamped cnvelope.

A visitor group was defined as one or more persons visiting the forest together; they were given one questionnaire and asked to complete it, either by consensus or to reflect the views of one group member. A total of 634 and 619 surveys were distributed in 1992 and 1993, respectively, of which 508 and 478 were completed. This provided a total response rate of nearly $80 \%$. We considered the rate to be adequate on the basis of similar appearance and conversational characteristics between respondents and non-respondents (Mendenhall et al. 1971). Because all questions were not answered on every questionnaire, the sample size varied slightly with specific hypotheses tested.

Sample collection was devised to assure proportional representations from weekday vs. weekend and early-, mid- and late-season visitors. The sample was stratified by recreation opportunity spectrum (ROS) class. Spectrum class is a procedure used by recreation managers that offers, among other products, criteria for classifying lands according to 7 classes of recreation opportunity ranging from primitive to urban (Driver and Brown 1978). Most of the non-wilderness part of the watershed is classified as roaded natural or semi-primitive motorized.

The questionnaire asked for information about various demographic attributes, including location and size of the visitor's home community. Individual answers describing place of residence were coded into 8 mutually-exclusive categories: (1) Local (Montrose and Gunnison Counties); (2) West Slope (Colorado, west of continental divide); (3) Front Range (Colorado, mountains and adjacent plains east of continental divide, including the cities of Fort Collins, Denver, Colorado Springs and Pueblo); (4) Eastern Colorado; (5) Other Rocky Mountain States; (6) West Coast; (7) Texas; (8) other parts of the United States. International respondents were not considered because they constituted an insignificant part of the sam- 
ple. The 4 categories outside of Colorado were specified to provide roughly similar sample sizes.

Community population size was recorded into 5 classes; rural, $<10,000,10,000-49,999,50,000-99,999,100,000-$ $300,000,>300,000$. Visitors were asked the size of both their present community and the one in which they grew up.

The person distributing the questionnaire recorded the recreational opportunity spectrum class and location (campground, dispersed area, other) where the respondent was encountered. After preliminary examination, the classes were reduced to (1) developed campgrounds (roaded natural) and (2) dispersed campsites (semi-primitive roaded) in the analysis because of insufficient sample sizes in other classes. Developed campgrounds were those providing multiple campsite locations, and generally having facilities such as tables, latrines, and fireboxes.

The questionnaire was designed to capture the degree to which livestock grazing was consequential as an issue within National Forest lands in the Big Cimarron watershed. This was accomplished with several questions where respondents were given an opportunity to make such a judgment upon their own volition. The first question asked whether anything lad interfered with their enjoyment of the area. If visitors answered yes, a follow-up question invited them to identify the causes of such interruptions. We expected cattle to be mentioned here if grazing conflicted with recreational activities. Responses were coded to keep track of up to 2 different causes per questionnaire, the first of which was assumed to be most important.

In 2 other open-ended questions, visitors were asked whether they noticed any harmful impacts to the natural environment around them, and, if so, were there changes they would like to see in the way the area was managed. Respondents believing livestock presence to be a factor causing environmental degradation would be expected to mention cattle in both questions.

Respondents were also afforded a chance to emphasize grazing as a point of contention or, alternatively, a beneficial experience in a following question that asked them to point out various occurrences encountered on their forest visit. This was done by soliciting how such interactions affected their overall experience; i.e., detracted a lot, detracted some, neither, added some, added a lot. Subjects included; other people, campground hosts, Forest Service personnel, wildlife, livestock, horseback riders, dogs or other pets, fishermen or hunters, off-road vehicles, mountain bikers, and backpackers. Unlike the first questions, livestock was listed here as one among a number of possible causal factors, although both positive and negative connotations were possible.

Preliminary analysis of 1992 data $(\mathrm{P}<.05)$ indicated the 8 coded resident locations could be consolidated into 3 broader areas on the basis of similar responses to the open-ended question, "Has anything interfered with your enjoyment of the area?". They were Rural Colorado, Front Range/Rocky Mountain States, and West Coast/Texas. The 'Other U.S.' category was included in Front Range/Rocky Mountain States. These 3 areas were used to analyze 1993 and combined responses.

Relationships between forest visitor demographics were evaluated using chi-square analysis. Chi-square was also employed to examine relationships between visitor demographics and their perceptions of livestock grazing, as well as between-year variation.

Attitudes from the question asking how various encounters had affected visitor's overall experience were appraised by a rating scale ranging from -2 (detracts a lot) to +2 (adds a lot), as described by Brown and Daniel (1990). This approach allowed the expression of strongly held opinions in the analysis. Visitor attitude was investigated as both a weighted average of the scales and their respective frequencies, directly, using chi-square analysis.

\section{Results}

With one exception, visitors' place of residence, the respondent characteristics did not differ between 1992 and 1993 $(\mathrm{P}<.05)$ (Table 1). Even that difference may not be meaningful, given that unrealistically small disparities can be detected

Table 1. Proportion of visitors to the Big Cimarron watershed, Uncompahgre National Forest, Colo., fitting different demographic characteristics, 1992-93.

\begin{tabular}{lll}
\hline & $\begin{array}{c}1992 \\
(\mathrm{n}=508)\end{array}$ & $\begin{array}{c}1993 \\
(\mathrm{n}=478)\end{array}$ \\
\hline Respondent Place of Residence & & \\
$\quad$ Rural Colorado (incl. local) & $.45^{*}$ & .55 \\
Front Range/Rocky Mountain ${ }^{1}$ & $.42^{*}$ & .33 \\
$\quad$ West Coast/Texas & .13 & .12 \\
Respondent Community Size & & \\
Rural $(<10,000)$ & .41 & .50 \\
Urban (10,000-100,000) & .32 & .26 \\
Metropolitan $(>100,000)$ & .27 & .24 \\
Respondent Age & & \\
$\leq 30$ years & .12 & .13 \\
$31-50$ & .55 & .55 \\
$>50$ & .33 & .32 \\
Respondent Annual Household Income & & \\
$<\$ 20 \mathrm{~K}$ & .12 & .14 \\
\$20-39K & .39 & .35 \\
\$40-79K & .41 & .40 \\
$\geq \$ 80 \mathrm{~K}$ & .08 & .11 \\
\hline
\end{tabular}

* Significant $(\mathrm{P}<.05)$ between years.

${ }^{1}$ Includes 'Other U.S.' category because of statistical similarity (see text).

with large sample sizes (Mitchell et al. 1993).

Visitors to the Big Cimarron watershed were reasonably well distributed among 2 of the 3 areas of residence: Roughly one-half came from rural Colorado (local, west slope, other Colorado), while three-eighths traveled from the Colorado Front Range or other Rocky Mountain states. The Texas/West Coast category comprised the remaining oneeighth of the respondents (Table 1).

The Front Range/Rocky Mountain category was dominated by visitors from the Denver metropolitan area, since more than one-third marked '>300,000' for community size. The Texas/West Coast category was most evenly distributed with $20 \%$ coming from rural areas, $20 \%$ from cities exceeding 300,000 population, and the rest from intermediate-sized communities. 
Table 2. Primary sources of interference perceived by visitors to the Big Cimarron watershed, Uncompahgre National Forest, Colo. 1992-93.

\begin{tabular}{lcc}
\hline Source of Interference & $\frac{1992}{(\mathrm{n}=461)}$ & $\frac{1993}{(\mathrm{n}=433)}$ \\
\hline None & .50 & .46 \\
Cattle & .09 & .09 \\
Weather & $.07 * \%$ & .02 \\
Insects & .05 & .05 \\
Other People & .06 & .07 \\
All Terrain Vehicles & .04 & .04 \\
Road Conditions & $.03 \%$ & .09 \\
Lack of Facilities & .02 & .02 \\
Trash and Litter & - & .02 \\
Other Sources & .14 & .14 \\
\hline
\end{tabular}

* Signilicant $(P<.01)$ between years.

Without knowing that the survey was designed to appraise interactions between livestock grazing and recreation, $9 \%$ of the respondents listed livestock as the first, or most important, source of interference with their enjoyment of the Big Cimarron watershed during both years of the study (Table 2). No visitor mentioned livestock as a second detractor in 1992 and only 5 did in 1993 ( $P>.05$ between years); the subject was either evoked initially or not at all. One-half of those responding could think of nothing that interfered with their visit.

The mention of livestock as a source of interference varied with visitors' home location in $1992(\mathrm{P}<.01)$. People from rural Colorado, including local residents, specified livestock slightly less than $5 \%$ of the time; those from the Front Range/Rocky Mountain states were intermediate at $10 \%$, while $25 \%$ of the visitors from Texas/West Coast made such a notation. In 1993, however, visitors' stipulation of grazing as a source of interference was independent of home location $(\mathrm{P}>$.9).

When both years were combined, the relationship was again significant $(\mathrm{P}<.05)$. In comparison to all visitors, people from rural Colorado were less likely to identify livestock as a source of interference, while residents of Texas/West Coast were more likely to do so. Respondents from the Front Range/Rocky Mountain states followed the pattern of all visitors, combined.

No apparent relationship existed between the size of a visitor group's present home community and its mention of livestock as a cause for restraining their enjoyment in either year $(\mathrm{P}>$.35). There was also no relationship with childhood community size $(P>.5)$. This lack of association corroborates findings by Watson and Niccolucci (1992) regarding hiker-horse conflicts.

Ninety percent of all people responding to the survey camped at least one night in the Big Cimarron watershed; a likely result of the 1-hour drive on unpaved roads required to reach the area from U.S. Highway 50 . About $60 \%$ of the respondents camped in developed campgrounds while the remaining $40 \%$ camped in dispersed areas. Over both years, residents from rural Colorado were inclined to camp in dispersed sites while those from the Front Range/other Rocky
Mountain States concentrated at developed campgrounds $(\mathrm{P}<.05)$. Visitors from the West Coast and Texas showed no clear preference for 1 of the 2 spectrum class (ROS) categories.

A clear difference was seen in whether visitors listed livestock as a detractor to their enjoyment and where they camped. People in developed campgrounds were less likely to be annoyed by the presence of domestic animals than those found in dispersed sites $(\mathrm{P}<.01)$; i.e., $7 \%$ versus $13 \%$, respectively, over both years.

Approximately $70 \%$ of those visiting the Forest Service lands on the Big Cimarron did not notice any environmental impacts attributable to improper management. The same proportion of visitors as felt that livestock grazing interfered with their enjoyment of the area, $9 \%$, listed livestock as an environmental impact. The remaining $21 \%$ was distributed among other factors, such as litter, people, and ATV's. No significant difference existed between years ( $P>.9$ ).

The proportions of answers to the follow-up question asking for changes in the way the area is managed that would mitigate perceived environmental damage did not differ greatly. Ten percent of all visitors wanted cattle removed from the National Forest, while $60 \%$ could think of no needed changes. Again, there was no significant difference between years (P>.2).

The final question, that of livestock detracting, being neutral, or adding to the respondents' overall experience, varied between years (Table 3). In 1992, the proportions of visitors taking extreme positions (cattle either detract or add a lot to their experience) were higher than expected, and those who tended to be neutral were less than expected. In 1993, this situation was reversed. Since the changes were symmetrical around neutral $(0)$, the weighted average from the rating scale did not change. Only the chi-square analysis was significant $(\mathrm{P}<.05)$.

The mean for the rating scale was slightly negative in 1992 and 1993 (Table 3). The negative value signified that those who thought cattle detracted a lot from their experience outnumbered visitors who believed livestock presence added a lot.

Table 3. Percentage of visitors to the Big Cimarron watershed $(n=869)$ giving different responses to the question, "How did the presence of cattle affect your overall experience on this visit." Results are significantly different between years $(P<.05)$.

\begin{tabular}{|c|c|c|c|c|c|}
\hline Year & $\begin{array}{c}\text { Detracts } \\
\text { A Lot }\end{array}$ & $\begin{array}{c}\text { Detracts } \\
\text { Some }\end{array}$ & Neutral & $\begin{array}{l}\text { Adds } \\
\text { Some }\end{array}$ & $\begin{array}{l}\text { Adds } \\
\text { A Lot }\end{array}$ \\
\hline & \multicolumn{5}{|c|}{$-\ldots$} \\
\hline 1992 & 20 & 16 & 30 & 21 & 13 \\
\hline 1993 & 17 & 13 & 36 & 26 & 8 \\
\hline Overall & 19 & 14 & 33 & 23 & 11 \\
\hline Rating Scale & {$[-2]$} & {$[-1]$} & {$[0]$} & {$[+1]$} & {$[+2]$} \\
\hline \multicolumn{6}{|c|}{ Wcighted Averages Based Upon Rating Scale: } \\
\hline Year & Mean & Std. & Error & & \\
\hline 1992 & -.093 & & 61 & & \\
\hline 1993 & -.042 & & 59 & & \\
\hline
\end{tabular}




\section{Discussion and Conclusions}

The region where people live has an apparent influence upon their attitudes about grazing on Forest Service lands in the Big Cimarron watershed. It was not surprising that local visitors, who comprised $25 \%$ of the respondents, and others residing in rural areas of Colorado had a relatively favorable view of range livestock in comparison to those emanating from more metropolitan areas.

The similarity between the responses of those from west coast states and Texas was unexpected because of their disparate population size characteristics; i.e., roughly $40 \%$ of Texans came from communities of less than 10,000 people, while the same percentage of west coast visitors were from cities exceeding 300,000 people. In addition, Texas contains more cattle than any other state in the U.S. (U.S. Department of Agriculture 1992). We could find no statistical justification for concluding that Texas respondents influenced the independence between community size and perceptions about livestock for all visitors.

The reason for such a congruence might be explained, in part, by effects of federal land patterns on residents of western states. Colorado and other states between the West Coast and the 100th Meridian are commonly called "public lands states." These states have developed under a tradition of grazing on Federally-managed rangelands (Public Land Law Review Commission 1970), which may influence attitudes of native and long-term residents.

There is also a possible explanation for between-year differences of the relative independence between where people live and perceptions about livestock interfering with their visit. Visitors to the study area mentioned poor road conditions as a primary distractor to their visits much more in 1993 than 1992 ( $\mathrm{P}<.01)$ (Table 2). Further inquiry (Personal communication, Mr. B. Patton, USDA-FS, Montrose, Colo.) ascertained that the county was involved in road construction and maintenance into the Big Cimarron basin during 1993, sometimes resulting in lengthy delays for motorists. Maslow's (1971) hierarchy of needs postulates that adverse physical conditions will preempt human attention over social and egotistic needs. Thus, it is conceivable that some of the perceived impacts attributed to livestock could have been partially masked by the ordeal of driving on rough roads for visitor groups more used to pavement.

The argument against concluding that road maintenance practices impacted respondent answers about livestock grazing rests with the lack of any mention of grazing as a secondchoice source of interference with their visits in 1993. Even though 5 people did so, compared to none in 1992, the difference was insignificant.

There is one result that was seemingly inconsistent: Campers at dispersed sites were less favorably disposed towards encountering cattle than those in developed campgrounds; on the other hand, those same campers were more apt to be local and rural residents who, as a group, were less likely to be bothered by cattle. It is feasible, since dispersed camp sites were not fenced, that some visitors were actually responding to the consequences of camping where cattle had previously been. However, such an outcome could not be determined from our data.
Finally, an evaluation of answers to the question asking if livestock, among other causal factors, detracted or added to the visitor's experience is insightful. Over both years, the number of respondents indicating that range livestock added to their stay $(35 \%)$ was no different than the number stating a negative relationship (33\%). The proportion of these 2 groups with extreme views, i.e., adds a lot versus detracts a lot, was higher on the negative side than the positive (19\% and $11 \%)$. Such a result supports the viewpoint that opponents to public lands grazing policy are more prone to be non-compromising than those who do not dispute the present policy (Gillis 1991).

Although additional work is needed to validate the results in this report for other regions, 2 management implications are evident on a precursory basis. First, as long as livestock are kept out of developed campgrounds and adjacent riparian areas used for fishing and dispersed camping, especially during high recreation demand times, visitors to those locations will tend to be less disturbed by livestock herds on nearby rangeland than those in other dispersed camping areas. Second, any interpretive methods employed by Federal agencies to describe and explain how livestock grazing can be an integral part of rangeland ecosystem management should focus primarily on urban residents and all those visiting dispersed camping sites.

Notwithstanding the above, as more and more people relocate to the Rocky Mountain region from California, Texas and other populated states, any perception differences among different regions should continue to diminish. Hopefully, managers will still have opportunities to deal with uncued concerns about cattle grazing as long as the fraction of visitors who believe the presence of cattle lessens the quality of their time on a National Forest with high recreational value stays as low as it is, about $10 \%$.

\section{Literature Cited}

Brown, G. and C. Harris. 1992. The USDA Forest Service: toward the new resource management paradigm? Society and Nat. Resources 5:231-245.

Brown, T.C. and T.C. Daniel. 1990. Scaling of ratings: concepts and methods. USDA For. Serv. Res. Pap. RM-293.

Brunson, M.W. and B.S. Steel. 1994. National public attitudes toward Federal rangeland management. Rangelands 16:77-81.

Burde, J.H. and J. Lenzini. 1980. Timber harvest and aesthetic quality: can they coexist?, p.121-132. In: D. Hawkins, E. Shafer, and J. Robelstad (ed.) Tourism development and planning issues. George Washington University, Washington, D.C.

Driver, B.L. and P.J. Brown. 1978. The Opportunity Spectrum concept and behavioral information in outdoor recreation resource supply inventories: a rationale, p.24-31. In: H.G. Lund, V.J. LaBau, P.F. Ffolliott and D. Robinson (tech. coord.) Integrated inventories of renewable natural resources: Proc. of Workshop. USDA For. Serv. Gen. Tech. Rep. RM-55.

Dunlap, R.E. 1991. Trends in public opinion toward environmental issues: 1965-1990. Soc. and Natur. Resources 4:285-312.

Gillis, A.M. 1991. Should cows chew cheatgrass on commonlands? BioScience 41:668-675.

Hartmann, L.A., H.K. Cordell, and H.R. Freilich. 1988. The changing future of outdoor recreation activities. Trends 25(4):19-23.

Heitschmidt, R.K. and J.W. Stuth (ed.). 1991. Grazing management: an ecological perspective. Timber Press, Inc., Portland, Ore. 
Kaiser, H.F., P.J. Brown, and R.K. Davis. 1988. The need for values of amenity resources in public natural resources management, p.7-12. In: G.L. Peterson, B.L. Driver and R. Gregory (ed.) Amenity resource valuation: integrating economics with other disciplines. Venture Publishing, Inc., State College, Penn.

Kessler, W.B., H. Salwasser, C.W. Cartwright, and J. Caplan. 1992. New perspectives for sustainable natural resource management. Ecol. Appl. 2:221-225.

Larmer, P. and R. Ring. 1994. Can planning rein in a stampede. High Country News 26(16):6-8. Paonia, Colo.

Maslow, A.H. 1971. The further reaches of human nature. Viking Press, Inc., N.Y.

Mendenhall, W., L. Ott, and R.L. Scheaffer. 1971. Elementary survey sampling. Duxbury Press, Belmont, Calif.

Mitchell, J.E., R. Elderkin, and J.K. Lewis. 1993. Seasonal heightweight dynamics of western wheatgrass. J. Range Manage. 46:147-151.
Public Land Law Review Commission. 1970. One third of the Nation's Land. A report to the President and the Congress. U.S. Govt. Printing Office, Washington, D.C.

U.S. Department of Agriculture. 1992. Agricultural statistics, 1992. Washington, D.C.

USDA Forest Service. 1989. A description of Forest Service programs and responsibilities. USDA Forest Serv. Gen. Tech. Rep. RM-176.

Watson, A.E. and M.J. Niccolucci. 1992. Place of residence and hiker-horse conflict in the Sierras, p.71-72. In: D.J. Chavez (tech. coord.), Proc. of Symposium on social aspects and recreation research. USDA For. Serv. Gen. Tech. Rep. PSW-132.

Wells, M.D. 1995. The application of a recreation conflict model to the public lands grazing controversy. Ph.D. Diss., Colorado State Univ., Fort Collins, Colo. 